\title{
BANTUAN ALAT TRAINER KIT MIKROKONTROLLER BERBASIS ARDUINO GUNA PENINGKATAN KEMAMPUAN BELAJAR BAGI SISWA DI PONDOK PESANTREN AL-MUJAHIDIN KM. 10 BALIKPAPAN
}

\author{
*Randis ${ }^{1}$, Hadi hermansyah ${ }^{2}$, Yudi Kurniawan ${ }^{3}$, Elizabeth Milaningrumi 4 \\ 1,2,3,4 Jurusan Teknik Mesin, Politeknik Negeri Balikpapan \\ *email: $\underline{\text { Randis@poltekba.ac.id }}$
}

\begin{abstract}
The partner community in the implementation of this community service is Pondok Pesantren Al-Mujahidin Km.10, Balikpapan. The aids service that have been given to this community services are module and trainer kit based on arduiono and also programming training with mikrokontroler. The process of this community service started with the designed the tools of the trainer KIT, then made trainer kit and learning module in order to make students easier learning independently, and the last step was giving this tools for partner community that is the head of Pondok Pesantrem Al-Mujahidin Km.10 Balikpapan. After that, did an evaluation to know the successful of this activity. In the preliminary of this community service, it will be held the training for boarding students, however because of pandemic covid 19 which is students still off until the end of the year therefore the training was cancelled.
\end{abstract}

Keywords: Pondok Pesantren Al-Mujahidin Balikpapan, trainer kit based on arduiono, mikrokontroler

\begin{abstract}
ABSTRAK
Masyarakat mitra dalam pelaksanaan program Pengabdian Kepada Masyarakat ini yaitu Pondok Pesantren Al-Mujahidin Km. 10 Balikpapan. Bantuan yang diberikan kepada masyarakat mitra yaitu pemberian berupa modul dan trainer kit berbasis arduino pelatihan pemrograman dengan mikrokontroller dan. Langkah pelaksanaan dengan perancangan alat trainer kit, selanjutnya membuat trainer kit serta modul pembelajaran untuk memudahkan siswa dalam belajar mandiri dan tahapan terakhir dilakukan serah terima alat kepada masyarakat mitra dalam hal ini pimpinan Pondok Pesantren Al-Mujahidin Km. 10 Balikpapan serta dilakukan evaluasi untuk mengetahui keberhasilan dari kegiatan ini. Rancangan awal kegiatan PKM ini juga akan melakukan kegiatan pelatihan terhadap siswa pesantren namun karena kondisi pandemi covid-19 dimana siswa masih sementara diliburkan sampai akhir tahun sehingga kegiatan pelatihan ini ditiadakan.
\end{abstract}

Kata kunci: Pondok Pesantren Al-Mujahidin Balikpapan, trainer kit berbasis arduino, mikrokontroller 


\section{PENDAHULUAN}

Pondok Pesantren Al-Mujahidin adalah sebuah sekolah berbasis asrama sehingga para siswanya diwajibkan tinggal di asrama dan terpisah dari orang tuanya. Terdapat dua instansi pendidikan di Pondok Pesantren Al-Mujahidin yaitu SMP Muhammadiyah 3 dan SMA Muhammadiyah 2 dimana masing-masing instansi mengajarkan ilmu pengetahuan umum dan ilmu agama. Sebagai salah satu lembaga pendidikan Islam yang ada di Kota Balikpapan, Pondok Pesantren Al-Mujahidin memiliki tujuan dalam menyelenggarakan pendidikan, salah satunya yaitu untuk menghasilkan generasi-generasi muslim dengan kemampuan atau bakat yang dapat diandalkan untuk mendukung kemandirian diri pribadi maupun kemandirian secara sosial sehingga dapat bersaing dalam dunia kerja nantinya (Ramadhani, 2018).

Pondok pesantren Al Mujahidin sebagai salah satu lembaga pendidikan Islam yang ada di Kalimantan Timur tepatnya di Kota Balikpapan yang memiliki fasilitas pendidikan yang cukup memadai, dan terus berupaya untuk menambah serta menyempurnakan fasilitas yang ada. Tujuan dalam menyelenggarakan pendidikan, salah satunya yaitu menghasilkan generasi Muslim dengan keterampilan yang dapat diandalkan untuk mendukung kemandirian pribadi dan kemandirian sosial (Almujahidinbpn, 2017)(Gozali, 2019).

.Pada beberapa sekolah kegiatan ekstrakurikuler siswa terbatas pada kegiatan olahraga dan kegiatan lain yang pembelajarannya masih sederhana sehingga perlu adanya kegiatan tambahan seperti pelatihan teknik pemprograman mikrokontroler/mikroprosesor kepada siswa guna menghadapi era revolusi industri 4.0 saat ini. Kegiatan pelatihan seperti ini dapat memberikan kesempatan belajar yang lebih dalam bagi siswa mengenai ilmu pemprograman dasar mikrokontroler. Untuk merancang sistem pengontrolan dengan mikrokontroler dibutuhkan dua keterampilan yaitu 1) perancangan dan perakitan hardware, 2) perancangan dan perakitan software (Edidas, 2018)

Kurangnya pengetahuan, keterampilan dan media pembelajaran juga menjadi masalah bagi para siswa dan juga guru untuk mempelajari ilmu dasar tentang elektronika seperti ilmu pemprograman dengan mikrokontroler dan tidak ada modul dan peralatan khusus untuk belajar ilmu tersebut. Sementara ilmu elektronika ini akan sangat berguna nantinya bagi para siswa saat akan melanjutkan ke jenjang perguruan tinggi maupun dalam dunia kerja ( Karimah, S. N. (2015), (Zulkarnain, 2018), 
Sebagai upaya mengatasi permasalahan kegiatan ekstrakurikuler yang masih minim di kalangan para siswa maka dalam program pengabdian kepada masyarakat ini Politeknik Negeri Balikpapan sebagai penyedia memberikan pelatihan dan bantuan trainer kit berbasis Arduino kepada siswa Pondok Pesantren Al-Mujahidin sebagai mitra dari kegiatan ini. Trainer kit ini berbeda dengan program penelitian sebelumnya (Aldi dan Basuki, 2019)(Sahali, 2018), trainer ini sudah berbentuk modul yang rapih dengan berbagai komponen didalamnya sehingga memudahkan dalam proses pembelajaran siswa dirancang untuk meningkatkan kemampuan dan kompetensi siswa dalam mengaplikasikan mikrokontroler yaitu Arduino yang saat ini banyak digunakan. Kemampuan tersebut dapat menjadi modal dasar dan menambah pengetahuan bagi siswa agar nantinya saat di jenjang perguruan tinggi tidak merasa awam ataupun bingung lagi mengenai mikrokontroler.

\section{METODE PELAKSANAAN}

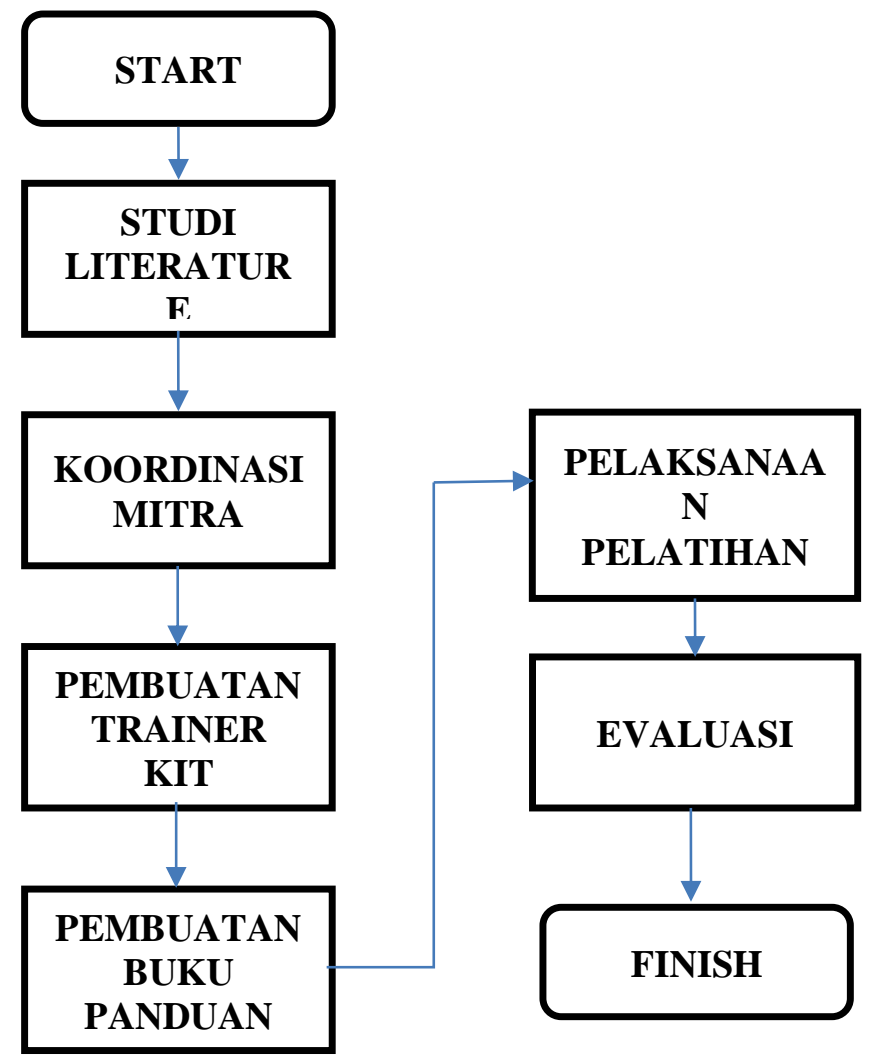

Gambar 1. Flow Chart Pelaksanaan kegiatan PKM 
Tahapan pelaksanaan kegiatan ini di laksanakan dengan mengacu pada diagram alir sebagaimana yang diperlihatkan pada gambar 1. Secara umum kegiatan ini dibagi ke dalam 3 tahap, yaitu tahap persiapan, tahap pelaksanaan dan tahap evaluasi. Tahap persiapan dilakukan dengan koordinasi dengan mitra untuk mengetahui kebutuhan mitra yang bersangkutan, selanjutnya dari koordinasi mitra dapat dipetakan dan dirumuskan permasalahan mitra sehingga dapat ditemukan solusi yang tepat untuk menyelesaikan permasalahan yang sedang dihadapi oleh mitra.

Selanjutnya tahap pelaksanaan, pada tahapan ini ada beberapa kegiatan yang dilakukan yaitu perencanaan desain alat trainer kit yang akan dibuat, pembuatan alat sesuai dengan desain awal yang telah dibuat, pembuatan buku panduan siswa (Modul praktikum) dan terakhir adalah spelaksanaan serah terima modul trainer kit bagi siswa dilingkungan mitra. Tahapan selanjutnya yaitu evaluasi, untuk mengetahui tingkat keberhasilan mitra, hasil evaluasi akan dijadikan sebagai bahan pertimbangan untuk melakukan perbaikan-perbaikan dan kekurangan ini dapat disempurnakan pada pelaksanaan kegiatan PKM selanjutnya. Program PKM ini akan diupayakan dilakukan secara berkala untuk meng-upgrade ilmu pengetahuan para siswa terhadap teknologi ini.

\section{HASIL DAN PEMBAHASAN}

\section{a. Tim Pelaksana Kegiatan PKM}

Untuk keberhasilan program Pengabdian Kepada Masyarakat (PKM) ini maka keanggotaan tim pengabdian ini terdiri dari beberapa dosen dengan bidang keahlian yang dibutuhkan dengan kualifikasi multi disiplin ilmu. Secara garis besar ketua tim pengusul kegiatan ini memiliki keahlian dalam mikrokontroller khususnya yang berbasis pada arduino. Selanjutnya anggota tim yang lainnya memiliki keahlian dalam fabrikasi yang dapat digunakan untuk membuat dan membangun trainer kit, dan anggota lainya membantu dalam pelaksanaan kegiatan dalam hal mempersiapkan peralatan dan perlengkapan pada saat pelaksanaan kegiatan.

Dalam pelaksanaan kegiatan Program kemitraan masyarakat (PKM) ini tim pengusul juga melibatkan dua (2) orang mahasiswa sebagai asisten pendamping pada waktu kegiatan berlangsung serta membantu dalam proses fabrikasi dan perakitan alat. 


\section{b. Pelaksanaan Kegiatan PKM}

\section{Merancang dan mendesain alat trainer kit arduino}

Kegiatan awal pelaksanaan kegiatan PKM dilaksanakan dengan melakukan desain dan perancangan koper trainer kit arduino, selanjutnya desain ini digunakan untuk mencetak gambar pada tampak depan dari koper trainer kit arduino yang akan dibuat, selanjutnya modul pembelajaran guna memudahkan dalam proses belajar siswa. Tampilan desain koper depan alat trainer kit arduino yangg dibuat diperlihatkan pada gambar 2. Sementara untuk alat trainer kit arduino serta modul pembelajaran yan telah jadi diperlihatkan pada gambar 2 .

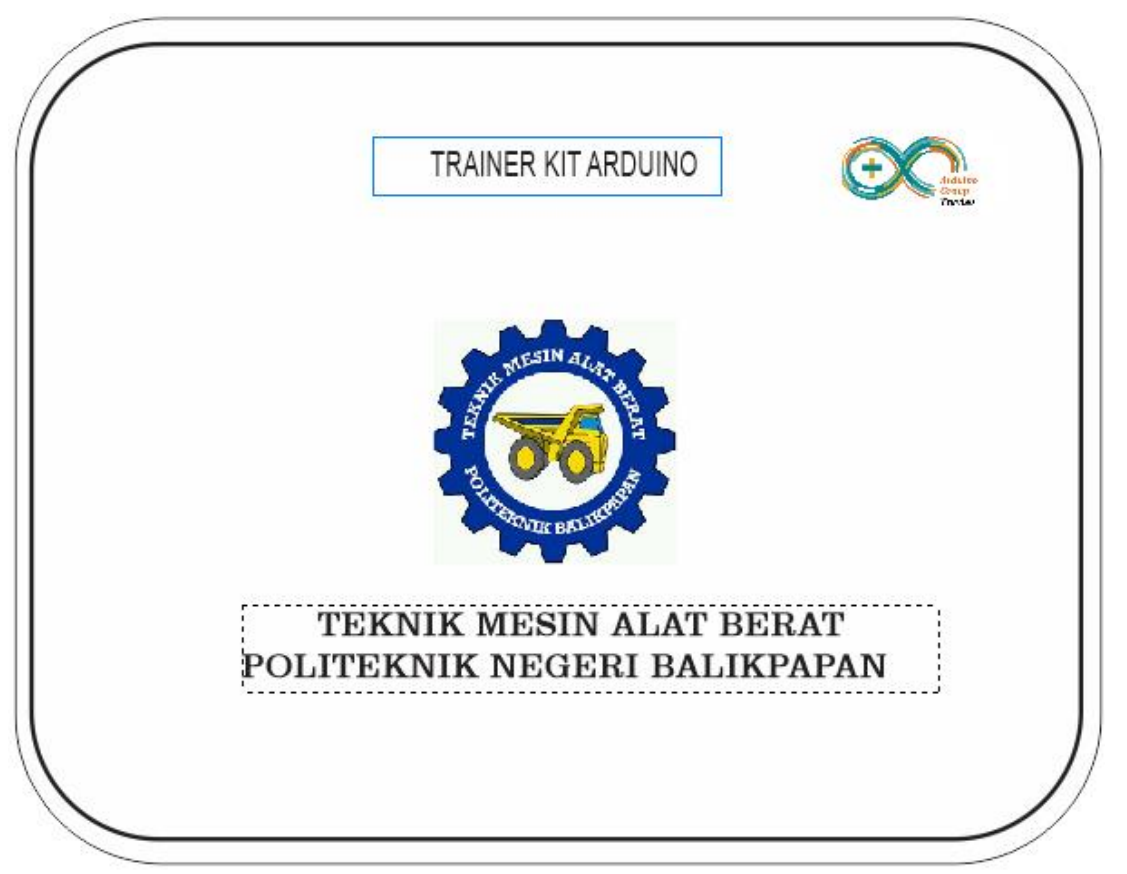

Gambar 2. Tampilan desain koper depan alat trainer kit Arduino

\section{Membuat dan merakit alat trainer kit arduino}

a. Tahapan awal dalam merakit dan membuat alat trainer kit arduino dilakukan dengan pemotongan pada mika sebagai dudukan dari komponen, Melakukan pengeboran pada mika sebagai dudukan bagi komponen elektronika yang akan ditempatkan serta sebagai dudukan pada koper atau modul yang akan dibuat, jarak dan jumlah lubang disesuaikan dengan papan pcb komponen, selanjutnya Melakukan pengikiran/ pengaplasan pinggiran pada mika untuk menghindari goresan akibat terkena mika tersebut hal ini juga dimaksudkan untuk membuat ukuran yang betul-betul presisi dengan koper atau modul 
yang digunakan, tahap terakhir dilakukan dengan melakukan pengeboran pada koper. Hal ini sebagai pondasi dan tempat meletakkan papan mika. Tahapan kegiatan ini diperlihatkan pada gambar 4 .

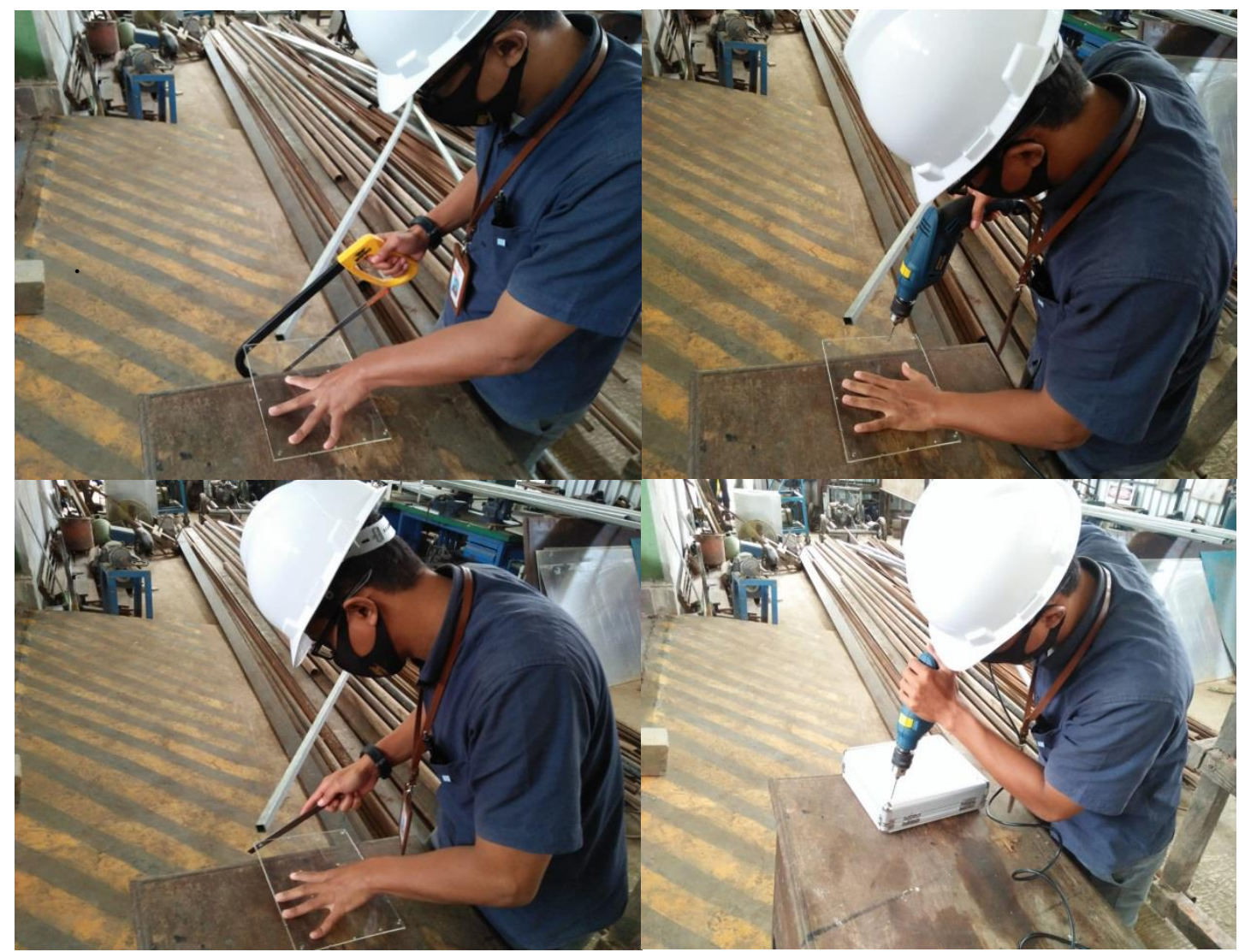

Gambar 4. Pelaksanaan Kegiatan berupa fabrikasi

b. Tahapan selanjutnya dalam merakit modul atau trainer kit ini yaitu melakukan pemasangan baut pada koper untuk mengikat mika dengan koper juga sebagai landasan bagi pcb dan komponen lainnya, melakukan pemasangan baut spenser pada mika untuk menahan pcb dan komponen, memasang mika yang telah dipasangi spenser pada koper, melakukan pemasangan seluruh komponen pada pcb, memasang seluruh sekrup untuk mengikat antara pcb dan mika, melakukan uji coba alat dengan memasukkan program, serta merangkai komponen dengan menggunakan kabel malefemale dan menguji coba beberapa rangkaian dalam modul. Tahapan dalam pelaksanaan kegiatan ini diperlihatkan pada gambar 5 . 


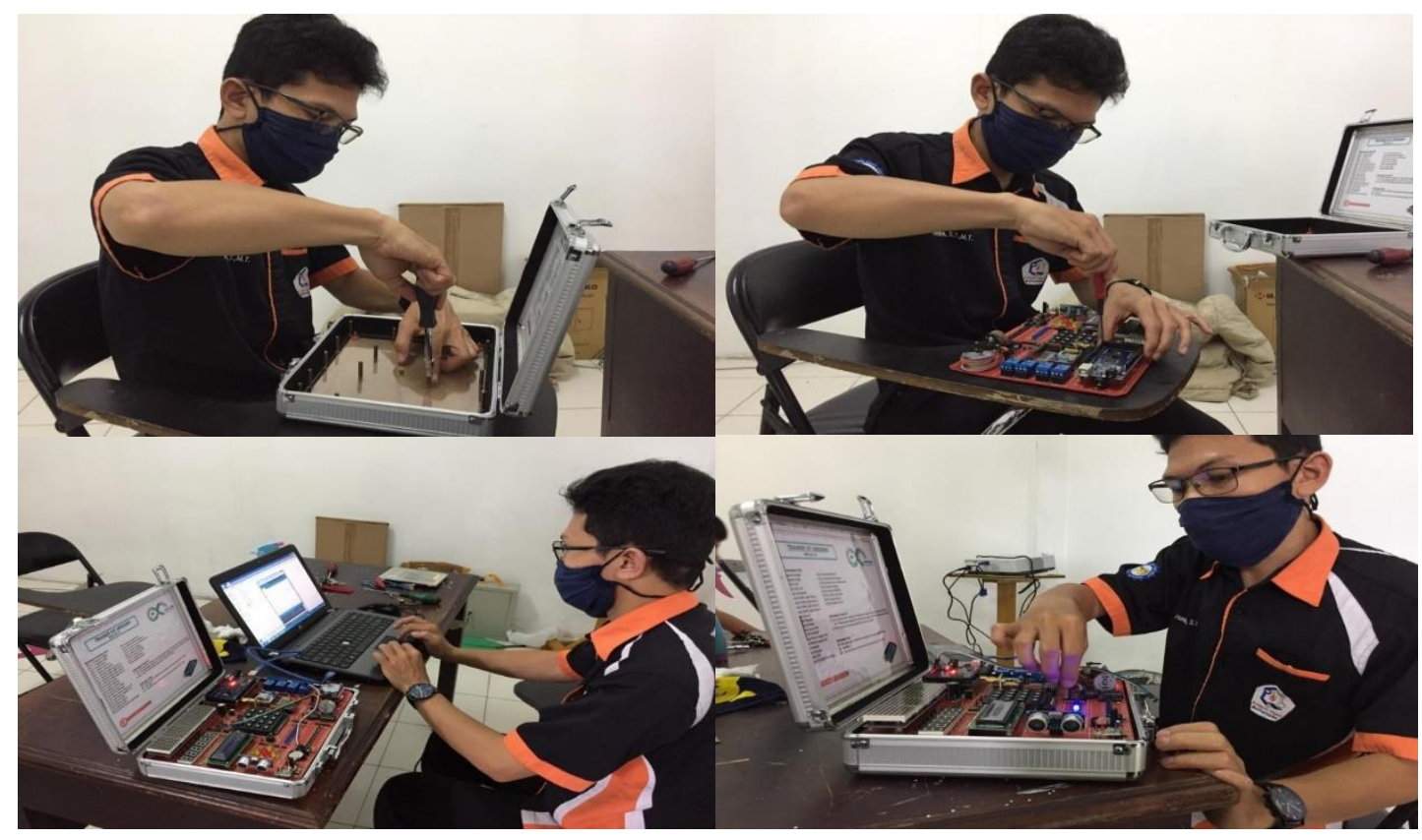

Gambar 6. Pelaksanaan Kegiatan berupa perakitan dan uji coba

Tujuan akhir kegiatan PMM adalah membantu para siswa dilingkungan pondok pesantren Almujahidin Balikapapan dalam mengenal dan memahami aplikasi dan penggunaan mikrokontroller berbasis arduino serta memberikan alat berupa trainer kit kepada pihak pondok pesantren untuk dapat dipergunakan sebagaimana mestinya.

c. Terakhir pada pelaksanaan kegiatan ini yaitu penyerahan alat serta serah terima modul trainer kit kepada pihak pimpinan Pondok pesantren (Gambar.7), alat modul trainer kit berbasis Arduino ini terdapat 23 Device yang dapat dibuat menjadi berbagai proyek ardlluino yang dapat dikembangkan ini terdiri atas 39 projek pembelajaran yang mendapat tambahan berupa 17 tugas (Gambar.8) yang dapat digunakan untuk mengasah kemampuan pengetahuan siswa dalam penggunaan modul trainer kit ini.

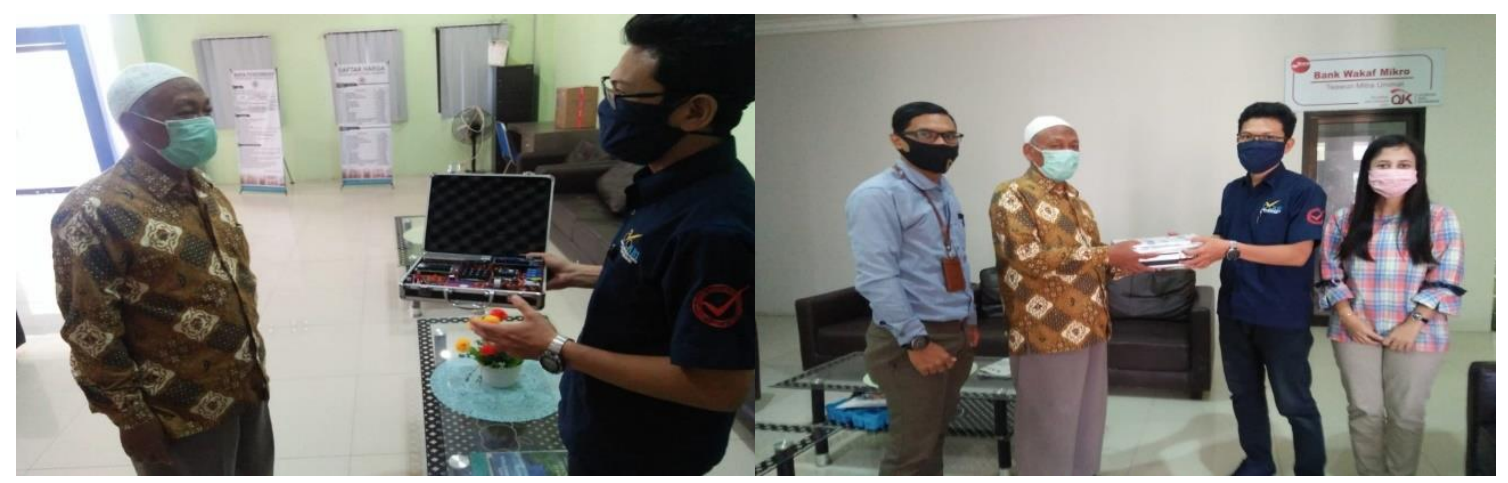

Gambar 7. Serah terima alat 


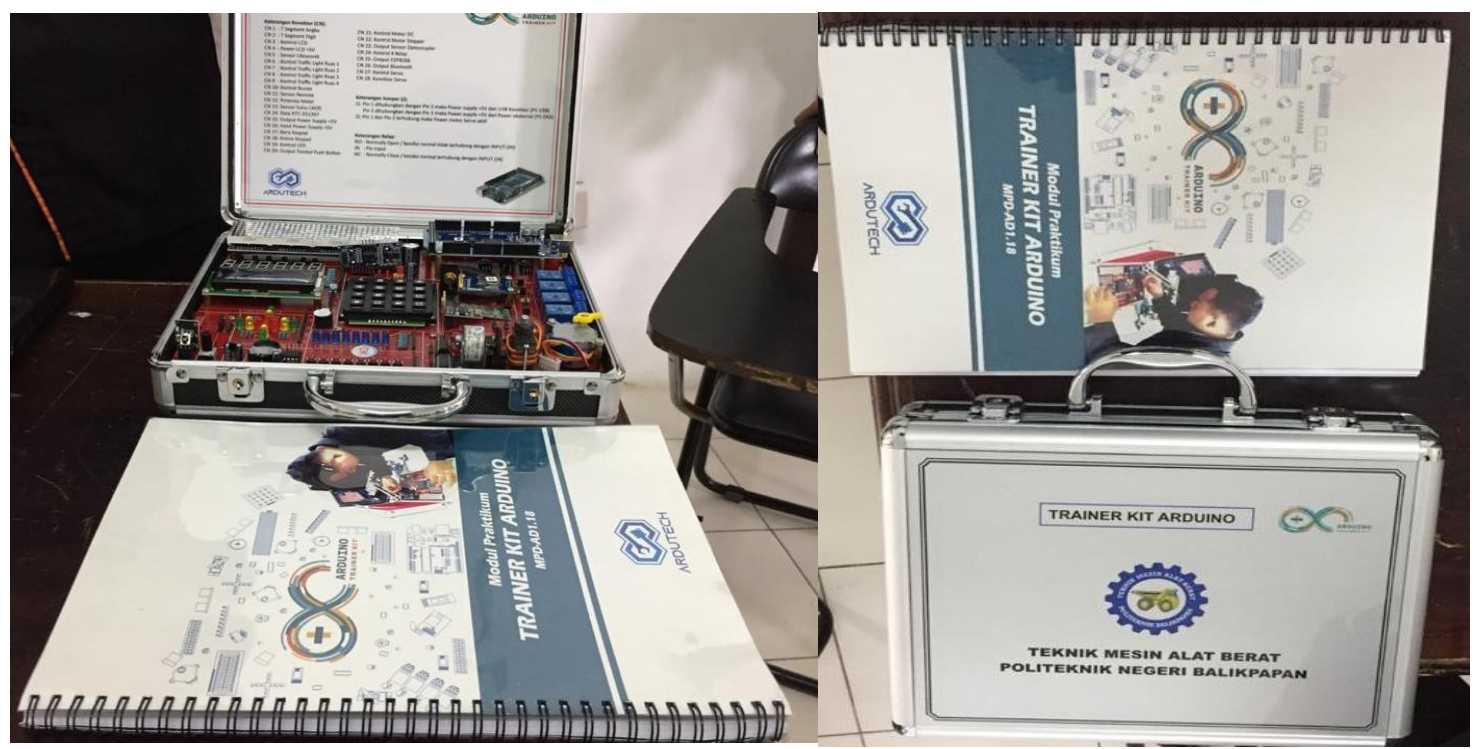

\section{Gambar 8. Modul dan trainer kit}

\section{KESIMPULAN}

Kegiatan pengabdian pada Masyarakat dengan mitra pelaksanaann kegiatan Pondok pesantren Al-Mujahidin Balikpapan telah dilaksanakan dengan menghasilkan luaran yang diharapkan. Dampak perubahan dari kegiatan ini yaitu tersedianya modul dan alat trainer kit berbasis arduino yang dapat digunakan bagi siswa pondok baik pada tingkatan SMP maupun SMA untuk menunjang pembelajaran ekstra kulikuler berbasiskan mikrokontroller arduino untuk peningkatan pengetahuan pada bidang elektronika dan robotik secara khusus.

\section{DAFTAR PUSTAKA}

Binti Zulkarnain, S. A. (2018). Pengaruh penggunaan media software proteus 8 professional terhadap hasil belajar pada mata pelajaran dasar listrik dan elektronika siswa kelas $\mathrm{x}$ teknik intstalasi tenaga listrik di smk negeri 1 percut sei tuan ta 2018/2019 (Doctoral dissertation, UNIMED).

Gozali, G., Kusuma, B. J., Mahfud, M., Soeparlan, A. A., \& Huda, M. (2019). Membangun Jiwa Entrepreunership Santri dan Santriwati Pondok Pesantren Al Mujahidin Balikpapan. Jurnal Abdimas Mahakam, 3(1), 18-23.

Karimah, S. N. (2015). Pengembangan alat praktikum seven segment dengan mikrokontroler pada mata kuliah elektronika dasar II (Doctoral dissertation, UIN Walisongo). 
Nehru, N., Aldi, A., \& Basuki, F. R. (2019). Pengembangan Modul Mata Kuliah Elektronika Dasar Ii Materi Robotika Untuk Meningkatkan Kemandirian Dan Pengetahuan. Edufisika: Jurnal Pendidikan Fisika, 4(02), 1-16.

Ramadhani, S. (2018). Sistem Informasi Akademik Pondok Pesantren Al-Mujahidin Balikpapan (Doctoral dissertation, University of Muhammadiyah Malang).

Sahali, I. R., Faizal, A. S., Sadjad, R. S., Christoforus, Y., \& Achmad, A. (2018). Pelatihan Pengembangan Aplikasi Menggunakan Mikrokontroler untuk Meningkatkan Kompetensi Siswa SMK. JURNAL TEPAT: Applied Technology Journal for Community Engagement and Services, 1(2), 162-168.

Dziubal, Charles., et.al. (2018). "Blended learning: the new normal and emerging technologies. International Journal of Educational Technology in Higher Education volume 15, Article number: 3.

Thorne, K. (2003). Blended Learning: “How to Integrate Online and Traditional Learning”. London, UK: Kogan Page Limited. 